\title{
A case of condylar hyperplasia treated with a right condylectomy and exteriorisation of the right inferior alveolar nerve
}

\author{
Azhar Hussain, ${ }^{1}$ Tharsika Myuran, ${ }^{2}$ Robert Bentley ${ }^{1}$
}

${ }^{1}$ King's College Hospital London, UK

${ }^{2}$ ENT Department, St George's Hospital, London, UK

\section{Correspondence to} Dr Tharsika Myuran, tharsika@doctors.org.uk

Accepted 15 April 2016

CrossMark

To cite: Hussain $A$, Myuran T, Bentley R. BMJ Case Rep Published online: [please include Day Month Year] doi:10.1136/bcr-2016215215

\section{DESCRIPTION}

A 25 -year-old woman presented with a 10-year history of gradually increasing right-sided facial asymmetry. Over the preceding 6 months, she developed increasing trismus and right temporomandibular joint (TMJ) pain. There was no history of trauma, infection, other systemic diseases or facial surgery.

Extraoral examination revealed significant facial asymmetry with laterognathia to the left, and an elongated right ramus and body of mandible. There was mild clicking of the right TMJ, but no obvious locking and a normal occlusion.

An orthopantomogram and CT showed an enlarged right hemimandibular condyle and elongation of the right ramus with a comparatively normal left side (figure 1). An isotope scan showed active ongoing hyperplasia, confirming the clinical diagnosis of condylar hyperplasia.

The patient underwent a right condylectomy via a preauricular approach and a sagittal split osteotomy to recontour the inferior border of the mandible while preserving the inferior alveolar nerve. The interarticular disc was maintained and secured over the respective condylar neck.

Histology confirmed condylar hyperplasia: active endochondral ossification with normal haematopoiesis and adipose marrow. At writing, 12 months

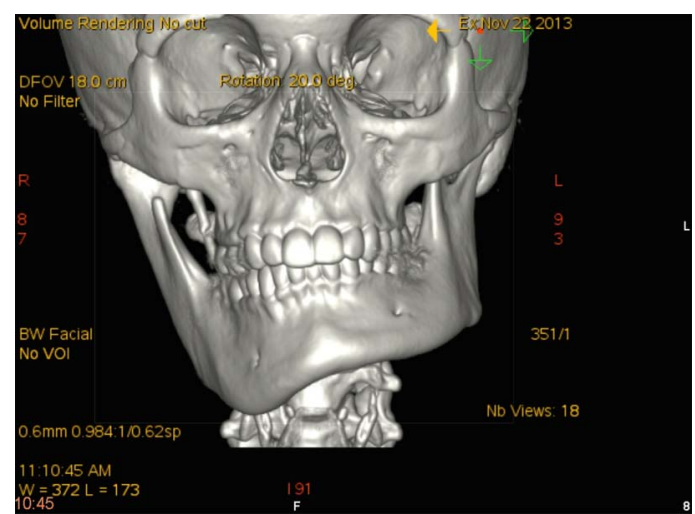

Figure 1 Three-dimensional $\mathrm{CT}$ reconstruction showing right-sided condylar hyperplasia.

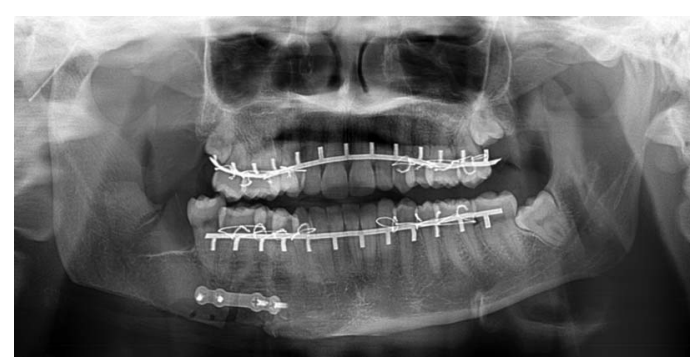

Figure 2 Postoperative orthopantomogram.

postoperatively, the patient has a well-balanced occlusion and excellent condylar function (figure 2).

Condylar hyperplasia is a non-neoplastic malformation of the mandible, usually unilateral and affecting a younger age group (20-30s). ${ }^{1}$ Although its aetiology is still uncertain, it is important to differentiate it from other causes of mandibular asymmetry such as osteochondromas, condylar resorption, trauma or infection related. ${ }^{2}$

\section{Learning points}

- Clinical and radiological information is key to diagnosis.

- Early diagnosis is crucial to allow best cosmetic and functional outcomes.

- Treatment is often surgical.

Competing interests None declared.

Patient consent Obtained.

Provenance and peer review Not commissioned; externally peer reviewed.

\section{REFERENCES}

1 Nitzan DW, Katsnelson A, Bermanis I, et al. The clinical characteristics of condylar hiperplasia: experience with 61 paients. J Oral Maxillofac Surg 2008;66:312-8.

2 Kawamoto HK, Kim SS, Jarrahy R, et al. Differential diagnosis of the idiopathic laterally deviated mandible. Plast Reconstr Surg 2009:124:1599-609. 


\section{Images in...}

Copyright 2016 BMJ Publishing Group. All rights reserved. For permission to reuse any of this content visit http://group.bmj.com/group/rights-licensing/permissions.

BMJ Case Report Fellows may re-use this article for personal use and teaching without any further permission.

Become a Fellow of BMJ Case Reports today and you can:

- Submit as many cases as you like

- Enjoy fast sympathetic peer review and rapid publication of accepted articles

- Access all the published articles

- Re-use any of the published material for personal use and teaching without further permission

For information on Institutional Fellowships contact consortiasales@bmjgroup.com

Visit casereports.bmj.com for more articles like this and to become a Fellow 